УДК 330.44

\author{
ИНФОРМАЦИОННОЕ СОГЛАСОВАНИЕ \\ НАРОДНОХОЗЯЙСТВЕННОЙ И ОТРАСЛЕВОЙ МОДЕЛИ \\ НА ПРИМЕРЕ ЛЕСНОГО КОМПЛЕКСА РФ \\ Стойлова Алина Сергеевна \\ Аспирант, e-mail:stoylova.as@ mail.ru, \\ Машкина Людмила Вячеславовна \\ K.э.H., e-mail: ludmila.mashkina@gmail.com, \\ Блам Юрий Шабсович \\ K.э.н., e-mail: blamukel@ gmail.com, \\ Институт экономики и организации промышленного производства \\ Сибирского отделения Российской академии наук, \\ 630090, Россия, Новосибирск, проспект Академика Лаврентьева, 17
}

\begin{abstract}
Аннотация. Подход к моделированию, описанный в статье, позволяет на основе Оптимизационной Межрегиональной Межотраслевой Модели (ОМMM) сформировать отраслевую модель лесного комплекса производственнотранспортного типа. С помощью этой модели можно учесть заготовку и переработку лесного сырья, производство промежуточной и конечной продукции, действующие и новые мощности, нагрузку на лесной комплекс со стороны народного хозяйства, а также импорт, экспорт и транспортные связи между регионами. Переход от решения задачи на поиск максимума конечного потребления к задаче на нахождение минимума затрат на производство и перевод стоимостных показателей в натуральные позволяет привести модель к виду, наиболее подходящему для анализа отраслевых особенностей и прогнозирования развития лесного комплекса.
\end{abstract}

Ключевые слова: лесной комплекс, производственно-транспортная модель, ОМММ, отраслевая модель

Цитирование: Стойлова А.С., Машкина Л.В., Блам Ю.Ш. Информационное согласование народнохозяйственной и отраслевой модели на примере лесного комплекса РФ //Информационные и математические технологии в науке и управлении. 2020. № 4 (20). С. 124 131. DOI: $10.38028 /$ ESI.2020.20.4.011

Введение. Построение модификаций прогнозных моделей позволяет получить подходящий инструментарий для исследования проблемы хозяйственного взаимодействия субъектов экономики в условиях ограниченных ресурсов и интерпретировать дальнейшее развитие народного хозяйства, регионов и отдельных отраслей. Для построения прогнозов в рамках конкретной задачи необходимо оптимальным образом упростить сложные взаимодействия между субъектами, введя системы предположений, оценок и ограничений. При этом в ходе построения идеализированной математической модели требуется наиболее точно передать существующие взаимосвязи между компонентами, чтобы по результатам решения на основе полученной информации дать экспертные рекомендации.

Методы и материалы. В качестве основы для последующих структурных модификаций (рис. 1) выступает ОМММ (Оптимизационная Межрегиональная 
Межотраслевая Модель) [1, 5-8]. В эту модель входят балансовые ограничения по производству и распределению продукции, ограничения на трудовые ресурсы, инвестиции, ограничения на объемы выпуска и прироста продукции, ограничения на региональное внешнеторговое сальдо и внешнеторговый баланс, ограничения на объемы экспорта и импорта и ограничения на территориальную структуру конечного потребления. Исходная модель описывает 40 отраслей и 8 регионов, среди которых только 3 относятся к лесному комплексу:

- Деревообработка

- Целлюлозно-бумажная промышленность

- Охота и лесное хозяйство (лесозаготовки).

В начале работы производится модификация ОМММ с помощью процедур агрегации и дезагрегации. Модель приводится к специализированному виду, в ее информационном блоке сокращается количество отраслей, не относящихся к лесному комплексу, и увеличивается количество отраслей лесного комплекса. После всех начальных преобразований модель содержит 12 лесных и 13 не лесных отраслей. Эта модель получает название ОМММ25 и является основой для следующих преобразований $[2-4,10]$.

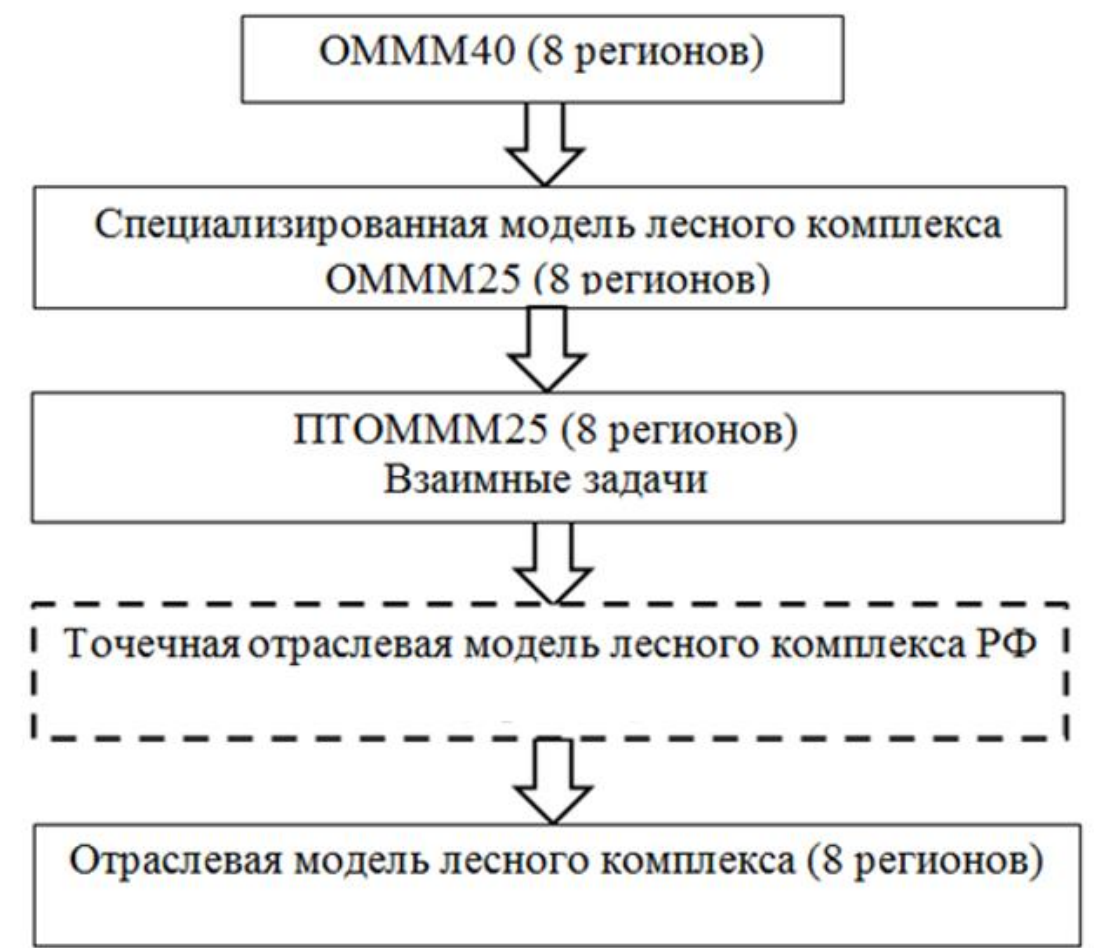

Рис. 1. Схема модификации ОМММ

На следующем этапе происходит переход от задачи на поиск максимума конечного потребления к задаче на нахождение минимума трудовых затрат с использованием теории взаимности (рис. 2) [9].

Обозначения к рис. 2:

$x_{j}, y_{j}-$ план производства для прямой и взаимной задачи соответственно;

$m$ - виды ресурсов в количестве $b_{1}, b_{2}, \ldots, b_{m}$ соответственно;

$n$ - виды продукции стоимостью $c_{1}, c_{2}, \ldots, c_{n}$ соответственно; 
$a_{i j}$ - нормы потребления ресурсов для производства единицы каждого вида продукции;

$d_{j}$ - дефицитный ресурс.

$\alpha$ - ограничение дефицитного ресурса

$\beta$ - величина максимальной прибыли

\begin{tabular}{|l|l|}
\hline \multicolumn{1}{|c|}{ Прямая задача } & \multicolumn{1}{c|}{ Взаимная задача } \\
\hline$\sum_{j=1}^{n} c_{j} x_{j} \rightarrow \max ;$ & \multicolumn{1}{|c|}{$\sum_{j=1}^{n} d_{j} y_{j} \rightarrow \min$} \\
$\sum_{j=1}^{n} d_{j} x_{j} \leq \alpha(\alpha>0) ;$ & $\sum_{j=1}^{n} a_{i j} y_{j} \leq b_{i}(1 \leq i \leq m)$ \\
$\sum_{j=1}^{n} a_{i j} x_{j} \leq b_{i}$ для $i=1, \ldots, m_{i}$ & $\sum_{j=1}^{n} c_{j} y_{j} \geq \beta(\beta>0)$ \\
& $y_{j} \geq 0 ;$ \\
\hline
\end{tabular}

Рис. 2. Схема перехода к взаимной задаче

На уровне оптимального решения фиксируется значение фонда конечного потребления, которое в дальнейшем принимается за ограничение снизу. Все ограничения исходной задачи сохраняются. Дополнительно вводится ограничение на трудовые ресурсы по стране в целом, которое является лимитирующим. Новая задача позволяет при фиксированном максимуме конечного потребления найти необходимый минимум трудовых ресурсов для его достижения [12, 13].

Далее совершается переход к отраслевой задаче производственно-транспортного типа. Переменные, не относящиеся к производству лесной продукции, её перевозкам, непроизводственному потреблению, экспорту и импорту, взвешиваются на значения, полученные в оптимальном решении ОМMM25, и переносятся в правую часть балансовых ограничений. Таким образом, формируется нагрузка на лесной комплекс со стороны народного хозяйства. Полученные при решении такой модели двойственные оценки можно интерпретировать, как стоимость продукции в трудовом выражении.

После формирования нагрузки на лесной комплекс из описания исключаются все трудовые затраты, относящиеся к производству лесной продукции не лесными отраслями. В результате среди балансовых ограничений задачи остаются только те, которые непосредственно связаны с производством лесной продукции и использованием трудовых ресурсов лесным комплексом в каждом регионе. Для завершения модификации выделенные показатели взвешиваются на полученные в ходе решения ОМММ25 оценки в трудовом выражении и суммируются с коэффициентами целевой функции.

Нагрузка на отрасль со стороны народного хозяйства переводится из стоимостных показателей в натуральные. Для этого рассчитываются цены за единицу продукции, которые затем умножаются на соответствующие показатели правых частей. После этого формируются новые блоки модели: блок заготовки и переработки сырья и промежуточной продукции. Технологические способы производства рассчитываются, исходя из данных, опубликованных отраслевыми институтами. С помощью статистической информации рассчитываются 
коэффициенты целевой функции, затраты на производство продукции лесопромышленного комплекса, средние цены на сырьё.

С использованием полученной отраслевой модели проводятся серии расчетов, которые можно использовать для интерпретации отраслевых документов (например, Стратегии развития лесного комплекса до 2030 года) $[11,14,15]$. В таблице 1 представлено сравнение среднегодовых темпов роста объемов производства, полученных с помощью точечной отраслевой модели, и Стратегии развития лесного комплекса РФ до 2030 года.

Таблица 1. Сравнение среднегодовых темпов роста объемов производства в точечной отраслевой модели (ТОМ-лк) и Стратегии-2030

\begin{tabular}{|l|c|c|c|}
\hline Темпы & ТОМ-лк & Стратегия (инерц.) & Стратегия (страт.) \\
\hline Пр-во пиломат. & 1.004 & 1.010 & 1.023 \\
\hline Пр-во фанеры & 1.012 & 1.018 & 1.029 \\
\hline Пр-во целлюлозы & 1.000 & 1.000 & 1.125 \\
\hline
\end{tabular}

Таким образом, результаты расчетов по точечной отраслевой модели показывают, что прогнозы Стратегии-2030 завышены.

Заключение. Отраслевая модель, построенная на основе ОМММ и информационно согласованная с ней, позволяет получить более детальный прогноз развития лесного комплекса. Модель такого рода содержит в себе одновременно информацию нижнего и верхнего модельных уровней - отраслевого и народнохозяйственного, - что позволяет анализировать отдельную (лесную) отрасль без отрыва от народного хозяйства страны.

\section{СПИСОК ЛИТЕРАТУРЫ}

1. Бабенко Т.И., Блам Ю.Ш., Машкина Л.В. СОНАР-ЛПК: средства моделирования и анализа лесопромышленного комплекса // Системное моделирование и анализ мезо- и микроэкономических объектов. Новосибирск: Изд-во ИЭОПП СО РАН. 2014. С. 147-183. 2. Блам Ю.Ш., Машкина Л.В., Стойлова А.С. Об одном подходе к детализации народнохозяйственного прогноза развития отрасли (на примере лесного комплекса) // Мир экономики и управления. 2016. Т. 16. № 4. С. 39-47.

3. Блам Ю.Ш., Машкина Л.В., Стойлова А.С. Детализация прогнозов по народнохозяйственной модели в натуральные показатели отраслевой модели (на примере лесного комплекса) // Экономика и управление инновациями. 2017. № 2. С. 66-77.

4. Блам Ю.Ш., Машкина Л.В. Построение иерархического набора моделей: от стоимостной ОМММ к отраслевой модели в натуральных показателях // Мир экономики и управления. 2018. Т. 18. № 4. С. 126-139.

5. Бузулуцков В.Ф., Суслов Н.И. СОНАР-ТЭК: моделирование и анализ проблем энергетического комплекса в системе национальной экономики // Системное моделирование и анализ мезо- и микроэкономических объектов. Новосибирск: Изд-во ИЭОПП СО РАН. 2014. С. 40-111.

6. Гранберг А.Г. Моделирование пространственного развития национальной и мировой экономики: эволюция подходов // Регион: экономика и социология. 2007. № 1. С. 87-107. 
7. Гранберг А.Г., Суслов В.И., Суспицын С.А. Многорегиональные системы: экономико-математическое исследование. Новосибирск: Сибирское Научное Издательство. 2007. 371 с.

8. Ершов Ю.С., Ибрагимов Н.М., Мельникова Л.В. Современные постановки прикладных межрегиональных межотраслевых моделей // Исследования многорегиональных экономических систем: опыт применения оптимизационных межрегиональных межотраслевых систем. Новосибирск: ИЭОПП СО РАН. 2007. С.29-59 9. Ицкович И. А. Анализ линейных экономико-математических моделей. Новосибирск: Наука. 1976. 190 с.

10. Мкртчян Г.М., Блам Ю.Ш., Машкина Л.В. Рациональное агрегирование отраслевой номенклатуры народнохозяйственной модели с детализированным лесным комплексом (оценка на основе экспериментальных расчетов) // Вестник Новосибирского государственного университета. 2015. Т.15. вып. 3. С. 56-63.

11. Об утверждении Стратегии развития лесного комплекса до 2030 года. Режим доступа: http://government.ru/docs/34064/ (дата обращения: 25.10.2020).

12. Стойлова А.С. Моделирование иерархии прогнозов: от стоимостного народнохозяйственного к "натуральному" отраслевому // Экономика Сибири в условиях глобальных вызовов XXI века. Ин-т экон. и организации пром. пр-ва СО РАН. Новосибирск: Изд-во ИЭОПП СО РАН. Т. 4. 2018. С. 228-239.

13. Стойлова А.С. Точечная отраслевая модель лесного комплекса как промежуточный этап комплексного моделирования // Актуальные вопросы экономики и социологии. Новосибирск: ИЭОПП СО РАН. 2019. ISBN 978-5-89665-343-1. С. 589-594.

14. Стойлова А.С. Оценка дефицитности крупномерного лесосырья в рамках стратегии развития лесного комплекса 2030 // Международная научная конференция "Экономическое развитие Сибири и Дальнего Востока. Экономика природопользования, землеустройство, лесоустройство, управление недвижимостью". Новосибирск: СГУГиТ. 2019. DOI: 2618-981X-2019-3-1. Т. 3. № 1. С. 231-238.

15. Стойлова А.С. Количественная оценка прогнозов "Стратегии развития лесного комплекса - 2030" на основе комплекса моделей // Мир экономики и управления. 2019. Т. 9. № 4. C. 114-126. DOI: 10.25205/2542-0429-2019-19-4-114-126 


\title{
UDK 330.44
}

\section{INFORMATION COORDINATION OF THE NATIONAL ECONOMIC AND INDUSTRY MODELS ON THE EXAMPLE OF THE RUSSIAN FEDERATION FORESTRY}

\author{
Alina S. Stoylova \\ Graduate student, e-mail: stoylova.as@mail.ru, \\ Lyudmila V. Mashkina \\ PhD in Economics, e-mail: ludmila.mashkina@gmail.com,

\section{Yuriy Sh. Blam} \\ PhD in Economics, , e-mail: blamukel@gmail.com, \\ Institute of Economics and Industrial Engineering \\ of Siberian Branch of the Russian Academy of Sciences, \\ 17, Academician Lavrentyev Avenue, Novosibirsk, 630090, Russia
}

\begin{abstract}
The modeling approach described in this article allows, on the basis of OIIM, to build the forestry industry model of the production-transport type. Using this model, it is possible to take into account the harvesting and processing of timber, the production of intermediate and final products, existing and new capacities, the load on the forest complex from the national economy, as well as import, export and transport links between regions. The transition from solving the problem of finding the maximum final consumption to the problem of finding the minimum cost of production and converting cost indicators into natural values allows to transform the model to the form most suitable for analyzing industry characteristics and predicting the development of the complex.
\end{abstract}

Keywords: forestry, model of the production-transport type, OIIM, industry model

\section{References}

1. Babenko T.I., Blam YU.SH., Mashkina L.V. SONAR-LPK: sredstva modelirovaniya i analiza lesopromyshlennogo kompleksa [SONAR-LPK: tools for modeling and analysis of the timber industry complex] // Sistemnoe modelirovanie i analiz mezo- i mikroekonomicheskih ob"ektov. Novosibirsk: Izd-vo IEOPP SO RAN =System modeling and analysis of meso- and microeconomic objects. Novosibirsk: Publishing house Institute of Economics and Industrial Organization of the Siberian Branch of the Russian Academy of Sciences. 2014. Pp. 147-183. 2. Blam YU.SH., Mashkina L.V., Stojlova A.S. Ob odnom podhode k detalizacii narodnohozyajstvennogo prognoza razvitiya otrasli (na primere lesnogo kompleksa) [On one approach to detailing the national economic forecast for the development of the industry (using the example of the forestry complex)]// Mir ekonomiki i upravleniya $=$ The world of economics and management. 2016 vol. 16. № 4. Pp. 39-47.

3. Blam YU.SH., Mashkina L.V., Stojlova A.S. Detalizaciya prognozov po narodnohozyajstvennoj modeli $\mathrm{v}$ natural'nye pokazateli otraslevoj modeli (na primere lesnogo kompleksa) [Detailing forecasts for the national economic model into physical indicators of the industry model (using the example of the forestry complex)] // Ekonomika i upravlenie innovaciyami = Economics and innovation management. 2017 № 2. Pp. 66-77. 
4. Blam YU.SH., Mashkina L.V. Postroenie ierarhicheskogo nabora modelej: ot stoi-mostnoj OMMM k otraslevoj modeli v natural'nyh pokazatelyah [Construction of a hierarchical set of models: from a value OIIM to an industry model in natural terms]// Mir ekonomiki i upravleniya = The world of economics and management. 2018 vol. 18. № 4. Pp. 126-139.

5. Buzuluckov V.F., Suslov N.I. SONAR-TEK: modelirovanie i analiz problem energeticheskogo kompleksa v sisteme nacional'noj ekonomiki [SONAR-TEK: modeling and analysis of the problems of the energy complex in the system of the national economy] // Sistemnoe modeliro-vanie i analiz mezo- i mikroekonomicheskih ob"ektov. Novosibirsk: IEOPP SO RAN = System modeling and analysis of meso- and microeconomic objects. Novosibirsk: Publishing house Institute of Economics and Industrial Organization of the Siberian Branch of the Russian Academy of Sciences. 2014. Pp. 40-111.

6. Granberg A.G. Modelirovanie prostranstvennogo razvitiya nacional'noj i mirovoj ekonomiki: evolyuciya podhodov [Modeling the spatial development of the national and world economy: evolution of approaches] // Region: ekonomika i sociologiya = Region: economics and sociology. 2007. № 1. Pp. 87-107.

7. Granberg A.G., Suslov V.I., Suspicyn S.A. Mnogoregional'nye sistemy: ekonomi-komatematicheskoe issledovanie [Multi-regional systems: economic and mathematical research]. Novosibirsk: Sibirskoe Nauchnoe Izdatel'stvo = Novosibirsk: Siberian Scientific Publishing House. 2007. 371p.

8. Ershov YU.S., Ibragimov N.M., Mel'nikova L.V. Sovremennye postanovki prikladnyh mezhregional'nyh mezhotraslevyh modelej [Modern formulations of applied interregional intersectoral models] // Issledovaniya mnogo regional'nyh ekonomicheskih sistem: opyt primeneniya optimizacionnyh mezhregional'nyh mezhotraslevyh system. Novosibirsk : IEOPP SO RAN = Research of multiregional economic systems: experience in the application of optimized interregional intersectoral systems. Novosibirsk: Publishing House Institute of Economics and Industrial Organization of the Siberian Branch of the Russian Academy of Sciences. 2007. Pp. 29-59

9. Ickovich I. A. Analiz linejnyh ekonomiko-matematicheskih modelej [Analysis of linear economic and mathematical models]. Novosibirsk. Nauka= Sience. 1976. 190 p.

10. Mkrtchyan G.M., Blam YU.SH., Mashkina L.V. Racional'noe agregirovanie otraslevoj nomenklatury narodnohozyajstvennoj modeli s detalizirovannym lesnym kompleksom (ocenka na osnove eksperimental'nyh raschetov) [Rational aggregation of the sectoral nomenclature of the national economic model with a detailed forestry complex (assessment based on experimental calculations)] // Vestnik Novosibirskogo gosudarstvennogo universiteta = Novosibirsk State University Bulletin. 2015. vol. 15. №3 Pp. 56-63.

11. Ob utverzhdenii strategii razvitiya lesnogo kompleksa do 2030 goda [On approval of the Strategy for the development of the forestry complex until 2030]. Available at: http://government.ru/docs/34064/ (accessed:25.10.2020) (in Russian)

12. Stojlova A.S. Modelirovanie ierarhii prognozov: ot stoimostnogo narodnoho-zyajstvennogo $\mathrm{k}$ "natural'nomu" otraslevomu [Modeling the hierarchy of forecasts: from the value of the national economic to the "natural" industry] // Ekonomika Sibiri v usloviyah global'nyh vyzovov XXI veka . Novosibirsk: Izd-vo IEOPP SO RAN = Economy of Siberia in the context of global challenges of the XXI century. Novosibirsk: Publishing House Institute of Economics and Industrial 
Organization of the Siberian Branch of the Russian Academy of Sciences. T. 4. 2018. Pp. 228239.

13. Stojlova A.S. Tochechnaya otraslevaya model' lesnogo kompleksa kak promezhutochnyj etap kompleksnogo modelirovaniya [The point forestry model as an intermediate step of complex modeling ] // Aktual'nye voprosy ekonomiki i sociologii. Novosibirsk: IEOPP SO RAN = Topical issues of economics and sociology. Novosibirsk: Publishing House Institute of Economics and Industrial Organization of the Siberian Branch of the Russian Academy of Sciences. 2019. ISBN 978-5-89665-343-1. Pp. 589-594.

14. Stojlova A.S. Ocenka deficitnosti krupnomernogo lesosyr'ya v ramkah strategii razvitiya lesnogo kompleksa 2030 [Scarcity assessment of heavy timber in the framework of the forestry development strategy 2030] // Mezhdunarodnaya nauchnaya konferenciya "Ekonomicheskoe razvitie Sibiri i Dal'nego Vostoka. Ekonomika prirodopol'zovaniya, zemleustrojstvo, lesoustrojstvo, upravlenie nedvizhimost'yu". Novosibirsk : SGUGiT = International scientific conference "Economic development of Siberia and the Far East. Economics of environmental management, land management, forestry, property management". Novosibirsk: Siberian State University of Geosystems and Technologies. 2019. DOI: 2618-981H-2019-3-1. Vol. 3. № 1. Pp. 231-238.

15. Stojlova A.S. Kolichestvennaya ocenka prognozov "Strategii razvitiya lesnogo kompleksa 2030" na osnove kompleksa modelej [Model-Based Quantitative Evaluation of 2030 Forestry Development Strategy]. DOI: 10.25205/2542-0429-2019-19-4-114-126 // Mir ekonomiki i upravleniya $=$ The world of economics and management. 2019. vol. 9. № 4. Pp. 114-126. 